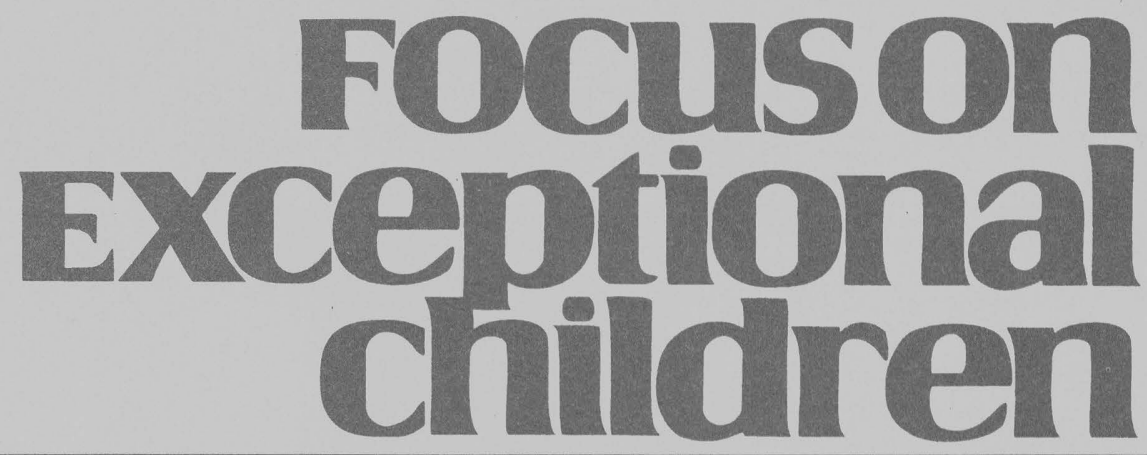

\title{
Strategies for Aligning Standards-Based Education and Transition
}

\author{
Diane S. Bassett and Carol A. Kochhar-Bryant
}

Over the past 20 years, major transformations have occurred in educational, social, political, and economic areas that continue to have an impact on the education and development of youth with disabilities and the institutions that support them. Approximately half of all students with disabilities in 2003-04 spent $80 \%$ or more of their day in a general education classroom with their nondisabled peers (National Center for Education Statistics, 2004), and antidiscrimination laws have improved access to postsecondary education and employment in a variety of occupations. The national investment is increasing to assist all individuals to access education and employment-preparation programs and foster social and economic independence. Interest in career development and transition is higher than it has ever been in the past, in the United States as well as other nations (Gordon, 1999). Successful transition from secondary education is becoming recognized as a chief indicator of the effectiveness of our educational system for preparing youth and young adults for employment, postsecondary education, military service, and adult independence.

Preparation for transition from school to adult life involves changes in the individual's self-concept, motivation, and development and is a fragile passage for the adolescent seeking to make difficult life choices (German, Martin, Marshall, \& Sale, 2000). This passage is even more delicate for youth with disabilities who need additional support and preparation to make the journey. For professionals seeking to help students on this journey, the process involves forming linkages among education and other human service agencies, including employment and training, adult services, and rehabilitation.

The concept of high school transition and preparation for careers has been emerging since the 1950s. Educators and policy makers have come to recognize the role of careervocational development in adolescent development and the importance of providing graduation pathways for youth with different postschool goals. Researchers have explored the range of interventions believed to be associated positively with improved graduation rates

Diane S. Bassett is a professor of special education in the School of Education in the College of Education and Behavioral Sciences at the University of Northern Colorado in Greeley, Colorado. Carol A. Kochhar-Bryant is a professor of special education in the Department of Teacher Preparation and Special Education in the Graduate School of Education and Human Development at the George Washington University in Washington, DC. 
and transition outcomes for youth with disabilities as they enter adult life roles (Benz, Lindstrom, \& Yovonoff, 2000; Barr \& Parrett, 2001; Blalock \& Benz, 1999; Clark, Sitlington, \& Kolstoe, 2000; deFur, 2000; Eisenman \& Chamberlin, 2001; Flexer, Simmons, Luft, \& Baer, 2001; Jorgensen, 1998).

Over the past three decades, special education and general education laws have promoted the inclusion of students with disabilities in general education classes-both academic and career-related-while also promoting supports for successful transition to postschool settings. As a result, educators are challenged to reconcile the individualized educational model for special education students with the general education model for all students.

\section{EXPANDING TRANSITION SERVICES}

The past 15 years have been marked by intense policy development and state and local capacity building aimed at improving education, employment preparation, and transition to postsecondary education for our nation's youth. Policy

\section{Focuson
Exceptional
children}

ISSN 0015-511X FOCUS ON EXCEPTIONAL CHILDREN (USPS 203-360) is published monthly except June, July, and August as a service to teachers, special educators, curriculum specialists, administrators, and those concerned with the special education of exceptional children. This publication is annotated and indexed by the ERIC Clearinghouse on Handicapped and Gifted Children for publication in the monthly Current Index to Journals in Education (CIJE) and the quarterly index, Exceptional Children Education Resources (ECER). The full text of Focus on Exceptional Children is also available in the electronic versions of the Education Index. It is also available in microfilm from Serials Acquisitions, National Archive Publishing Company, P.O. Box 998, Ann Arbor, MI 48106-0998. Subscription rates: individual, \$42 per year; institutions, $\$ 56$ per year. Copyright (C) 2006, Love Publishing Company. All rights reserved. Reproduction in whole or part without written permission is prohibited. Printed in the United States of America. Periodical postage is paid at Denver, Colorado. POSTMASTER: Send address changes to:

Love Publishing Company

Executive and Editorial Office P.O. Box 22353

Denver, Colorado 80222

Telephone (303) 221-7333

\section{EDITORIAL BOARD}

Lisa Dieker

University of Central Florida
Paula Maccini University of Maryland

Marleen Pugach

University of Wisconsin-Milwaukee

Susan T. Warhover Editor
Stanley F. Love

Publisher makers and advocates recognized the relationship between transition services and the achievement of postschool success for all youth. In the 1990s, several factors accelerated the implementation of transition service, including

1. the 1997 and 2004 IDEA reauthorizations;

2. NCLB and standards-based reforms in education;

3. passage of the Americans With Disabilities Act (ADA; PL 101-336), which is aimed at reducing workplace discrimination against individuals with disabilities;

4. the need for more workers in the economy;

5. federal initiatives to promote states' capacity to provide transition services; and

6. provisions in the Rehabilitation Act that promote coordination with secondary schools to improve transition support.

While the ad-hoc nature of policy making has contributed to an uncoordinated patchwork of youth programs and initiatives, efforts to develop and expand transition practices have endured.

In the 1990s, partly in reaction to public concerns about the eroding quality of education in the United States and weakening economic competitiveness, policy makers sought to improve student achievement through standards-based reforms. Improving education depended upon the creation of national standards to define what every student should know and be able to do (Jennings, 1995, 2000). The standards-based reform movement has shifted the attention of educators from preparation for work and career toward academic performance outcomes for all students.

More recently, leaders in education and job training are demanding a systematic redesign of secondary education and transition service delivery for all youth, particularly those with disabilities (Education Policy Reform Research Institute, 2004; Jorgensen, 1998; Patton \& Trainor, 2002). Reformers are promoting comprehensive and flexible youthdevelopment programs that integrate academic development, social-psychological development, career development, and preparation for work and broader life roles. Reformers argue that for students with the postschool goal of employment, the curriculum should blend both school-based and community-based approaches, particularly during the transition years, grades 9-12, and, if needed, through age 21. During these years students should be supported to concentrate on their career goals, and their education also should occur in the community, through work-study or work-based mentorship arrangements. The transition component of the IEP should emphasize the supports that students need to live independently, establish social lives, become lifelong learners, and sustain employment (Jorgensen, 1998). Since 1990, 
transition provisions in IDEA have supported a flexible, integrated, and coordinated planning approach for youth preparing for adult roles.

\section{SUMMARY OF MAJOR CHANGES RELATED TO TRANSITION FROM IDEA 1997 AND IDEA 2004}

The broad changes in transition requirements from 1997 to 2004 are summarized below.

\section{Change 1: Transition Services Moved from Age 14 to 16}

The 1990 IDEA required that transition services begin for students at age 16. The 1997 amendments to IDEA 1997 moved the date of initiation of transition services to age 14 (or younger, if the IEP team determines this to be appropriate), to be updated annually. The IDEA 2004 again shifts the age at which transition services are initiated from 14 back to age 16.

\section{Change 2: Shift in Emphasis to "Results"}

The 2004 statute places more emphasis on accountability of the educational system for improving transition outcomes for youth. IDEA 2004 modifies the definition of transition from an outcome-oriented process, which promotes movement from school to postschool activities to "a resultsoriented process, that is focused on improving the academic and functional achievement of the child to facilitate the child's movement from school to postschool activities."

This subtle change in language extended the focus on outcomes to highlight schools' responsibility for helping youth achieve the outcomes. IDEA 2004 requires that the student's IEP include “....appropriate measurable postsecondary goals based upon age-appropriate transition assessments related to training, education, employment, and, where appropriate, independent living skills ... and the transition services (including courses of study) needed to assist the child in reaching these goals" (IDEA 2004, Sec. 614).

\section{Change 3: Emphasis on Progress in the General Education Curriculum}

The 2004 IDEA emphasizes the goal of enabling the student to be involved in and progress in the general education curriculum. Students' participation in general education does not diminish but, rather, strengthens the need for aligning the course of study with individualized postschool transition planning.

\section{Change 4: An Exception to the Requirement to Evaluate Before Changing a Student's Status}

The 1997 law required a local education agency to evaluate a student with a disability before there was a change in his or her eligibility status for special education (i.e., determined to no longer be a child with a disability). IDEA 2004 includes an exception to the 1997 requirement for students who are (a) ending their eligibility as a result of graduation from secondary school with a regular diploma, or (b) exceeding the age of eligibility for special education under state law.

Instead, the LEA or district must provide the students with a "summary of academic achievement and functional performance (SOP), which shall include recommendations on how to assist the youth to meet their postsecondary goals" (Sec. 300.305(e)(3)). The SOP is cumulative and must reflect the effectiveness of a coordinated set of activities in helping youth achieve academic and functional progress.

\section{Change 5: Revision of "Statement of Interagency Responsibilities" in IEP}

The 1997 IDEA required that the IEP contain a "statement of needed transition services for the child, including, when appropriate, a statement of the interagency responsibilities or any needed linkages." The 2004 IDEA deletes this language in relation to transition services, but the state preserves language under the definition of the IEP and its components that the IEP include the

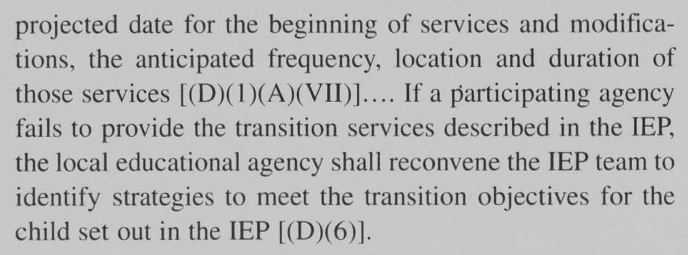

Interagency responsibility to provide needed services to support students' programs of study and postsecondary goals continues to be an expectation.

\section{Links Between NCLB and Transition}

The No Child Left Behind Act of 2001 (NCLB, PL 107110 ), first authorized as the Elementary and Secondary Education Act of 1965, also requires strategic cross-agency planning as well as collaboration to support students' transition from secondary education. In 2002, the President's Commission on Excellence in Special Education issued a report with 33 specific recommendations concerning individuals with disabilities, clustered around three broad themes:

1. Focus on results, not on process.

2. Embrace a model of prevention, not a model of failure.

3. Consider children with disabilities as general education children first. 
These recommendations dovetail with new requirements under NCLB that support collaboration and youth preparation for transition. The following two recommendations, in particular, echo NCLB provisions that support youth transition:

1. Mandate federal interagency collaboration to focus on transition services and better coordinate services to focus on reaching students with disabilities early.

2. Devote more attention to collaboration with families.

Several provisions in NCLB and the Rehabilitation Act mirror these recommendations and promote the transition of youth with disabilities and those at risk of school dropout.

\section{How the Rehabilitation Act Supports Transition}

Several provisions of the Rehabilitation Act Amendments of 1998 address coordination with high schools to improve transition services for students who will be eligible for vocational rehabilitation (VR) services after leaving school. Based on the same definition of transition services as that in IDEA, the Rehabilitation Act requires cooperation with education agencies responsible for the transition of students from school to employment or postsecondary settings. This provision links the IEP and the Individual Written Rehabilitation Plan (IWRP) under the Rehabilitation Act to accomplish rehabilitation goals before high school graduation. The Rehabilitation Act also provides for ongoing support services that can include assessment of employment needs at a worksite, job development and placement services, social skills training, or coordination of intensive services at the worksite or in the home that may be needed to maintain employment stability, independent living supports, and follow-up services.

\section{HOW NCLB AND IDEA PRINCIPLES DIFFER: CHALLENGES TO ALIGNING SBE AND TRANSITION}

In considering the twin goals of equity (access for all) and excellence (high standards) in education, the differences between the principles underpinning NCLB and IDEA must be understood. For more than two decades, the primary policy tool for improving outcomes for students with disabilities has been IDEA and its provisions for free and appropriate education and protection of individual rights. Standards-based education under NCLB represents a fundamentally different set of policies and practices that are based on uniform learning standards within a standards-based curriculum.

Standards-based education (SBE) is based on the assumption that common standards for all students are a catalyst for improved educational results. SBE is a basis for what should be taught and for measuring what students should be expected to know (Kochhar-Bryant \& Bassett, 2002; McDonnell, McLaughlin, \& Morison, 1997). SBE also is based on the assumptions that content and performance standards can be defined clearly and precisely, student performance can be measured validly and reliably using standardized assessments, and accountability can be strengthened through public reporting of aggregate data on student performance.

In contrast to the assumption of common performance standards, special education services are guided by the principle that students with disabilities be provided a free and appropriate education and that school systems be responsible to accommodate their individual needs (McDonnell et al., 1997). Individualized education relies on a private process. The IEP and transition plans are centered on the needs of the individual student, and students' individual rights are enforced through a set of procedural safeguards.

Also in contrast to the focus on academic outcomes that are the hallmark of standards-based education, the special education framework for students with disabilities encompasses a broader range of educational outcomes for students with disabilities. These broader outcomes include presence and participation, accommodation and adaptation, physical health, responsibility and independence, contribution and citizenship, academic and functional literacy, and personal and social adjustment (Ysseldyke, 1997; Ysseldyke, Thurlow, Kozleski, \& Reschly, 1998).

Critics of current standards-based education models claim that states have crafted standards that are too narrow and allow little room for educators to include nonacademic learning objectives such as those directed to social and behavioral skills, career and vocational development, physical and health development, and functional skills (Izzo, Hertzfeld, Simmons-Reed, \& Aaron, 2001; KochharBryant \& Bassett, 2002). To address the student's broader life domains, the foundation for transition must be laid during the elementary and middle school years, guided by the broad concept of career development and preparation of the whole person for postsecondary life. Table $1 \mathrm{com}$ pares the principles for transition and those for standardsbased education.

IDEA 1997 and 2004 emphasized the importance of an equitable accountability system and required states to include students with disabilities in general state and districtwide assessments and school improvement efforts. States now are required to establish goals for the performance of children with disabilities and to assess their progress toward achieving those goals. They must establish indicators such as student participation in assessments, dropout rates, graduation rates, and guidelines for alternative assessment of 
TABLE 1

Comparison of the Principles for Transition and Standards-Based Education

\section{Transition Principles}

1. The foundations for transition should be laid during the elementary and middle school years, guided by the broad concept of career development.

2. A broad range of educational outcomes for students with disabilities includes eight domains: presence and participation, accommodation and adaptation, physical health, responsibility and independence, contribution and citizenship, academic and functional literacy, personal and social adjustment, and satisfaction. ${ }^{2}$ The special education framework defines the rights of students with disabilities to a free and appropriate education and specifies the responsibilities of school systems to accommodate their individual needs.

3. Students' individual rights are enforced through a set of procedural safeguards, relying on a private process - the IEP - centered on the individual student. Transition planning should begin no later than age 14, and students should be encouraged to the full extent of their capabilities, to assume a maximum amount of responsibility for such planning. ${ }^{3}$

4. Transition means a coordinated set of activities aimed at a specific student outcome (e.g., employment, referral to rehabilitation services, enrollment in college) (IDEA '97). The coordinated set of activities must (a) be based on the individual student's needs, (b) take into account the student's preferences and interests, and (c) include needed activities in the areas of instruction, community experiences, the development of employment and other postschool adult living objectives, and, if appropriate, daily living skills and functional vocational evaluation.

5. Transition includes activities that promote the movement of a student from school to postschool activities, which may include postsecondary education, vocational training, integrated employment (including supported employment), continuing and adult education, adult services, independent living, and/or community participation.

6. Beginning when the student is age 14 and every year thereafter, the IEP must reflect the individual student's needs, taking into account the student's preferences and interests, and must include a statement of student's transition service needs in his or her courses of study. At age 16, specific transition services, a statement of interagency responsibilities, or any needed linkages are to be provided to the student.

7. The IEPs of students. with disabilities attending high school must reflect the general education curriculum and standards.

8. There is a change in status from student to adult roles in the community, including employment, participating in postsecondary education, maintaining a home, becoming appropriately involved in the community, and experiencing satisfactory personal and social relationships.

9. The process of enhancing transition involves participation and coordination of school programs, adult agency services, and natural supports within the community.

10. For students whose primary option is to enter the workforce after school, the curriculum is directed to vocational and functional skills and includes community-based instruction and vocational assessment.
Standards-Based Education Principles

1. Common standards that apply to all students are a catalyst for improved educational outcomes-serving as a basis for what should be taught and measuring what students should be expected to know. ${ }^{1}$

2. Academic and basic literacy outcomes are central, and there are shared curricular values.

3. Accountability is ensured through public reporting of aggregate data on student performance.

4. Content and performance standards can be defined clearly and precisely.

5. Student performance can be measured validly and reliably.

6. Instruction consistent with the standards can be implemented in individual schools and classrooms.

7. Higher standards will yield several results for students with disabilities ${ }^{4}$ :

a. The number of low-track English, math, and science classes will decrease.

b. More students will enroll in college preparatory classes.

c. Tracking will be eliminated.

d. Inclusion into general education will be promoted.

e. There will be broader options and improved transition outcomes for youth.

8. Creating rigorous learning standards within the curriculum will refocus teaching and learning on a common understanding of what schools expect students to know and be able to do.

Source: From Aligning Transition and Standards-Based Education by C. A. Kochhar-Bryant \& D. S. Bassett, 2002, p. 15. Copyright (c) 2002 by The Council for Exceptional Children. Reprinted with permission.

1 Educating One \& All: Students with Disabilities and Standards-Based Reform, by L. M. McDonnell, M. J. McLaughlin, \& P. Morison (Washington, DC: National Academy Press, 1997).

2 Accountability for the Results of Educating Students with Disabilities: Assessment Conference Report on the New Assessment Provisions of the 1997 Amendments to the Individuals with Disabilities Education Act, by J. Ysseldyke, M. Thurlow, E. Kozleski, \& D. Reschly (Minneapolis: National Center on Educational Outcomes, 1998).

3 The Transition of Youth with Disabilities to Adult Life, by A. S. Halpern, 1994 (a position statement of the Division on Career Development and Transition), Career Development for Exceptional Individuals, 17(2), 117.

4 Restructuring High Schools for All Students: Taking Inclusion to the Next Level, by C. M. Jorgensen (Baltimore: Paul H. Brookes, 1998). 
children with disabilities. IDEA, too, protects the child's right to "appropriate" and "individualized" methods for achieving common standards and goals, including nonacademic goals.

The challenge for educators is to align standards-based education policies with those under IDEA that are based on individual rights and individualized educational processes. Transition, therefore, must be viewed as a comprehensive framework (a) to ensure effective alignment between secondary education and transition services, and (b) to guide planning and decision making among students, families, and professionals (Kochhar-Bryant \& Bassett, 2002).

\section{TRANSITION AS A COMPREHENSIVE PLANNING PROCESS}

Educators are grappling with many complex questions as they attempt to comply with the mandate to improve access to the general education curriculum for students with disabilities (Jennings, 2003). Creative new approaches to blending the standards-based and individualized education approaches are being sought. The standards-based educational model is grounded in the assumption that all students should meet common standards for what should be taught and learned. The individualized education process, in contrast, is grounded in the principle of "appropriate" education that meets individual needs of each student who needs specialized educational services. Therefore, educators are asking: How can the standards-based curriculum be reconciled or aligned with the individualized education process? How should students with disabilities be included in standardized assessments? How do transition services "fit" within a standards-based educational system when a student participates in the general education curriculum?

Efforts to implement the federal transition requirements have been fraught with uncertainty about what is expected of states and local education agencies, families, and students. As a result, progress in implementing transition in many states has not resulted in significant improvement in postsecondary outcomes for youth. Many educators have called for a unified vision of middle and secondary education and transition planning (Clark et al., 2000; National Council on Disability, 2000; Thompson, Fulk, \& Piercy, 2000). New questions that have arisen about the relationship between transition and standards-based education include the following:

- Is transition supposed to fit into the standards-based reform movement, or do standards-based educational practices fit within the broader career development and transition framework for students with disabilities?

- To what extent do schools have the responsibility for preparing youth for careers if they are not bound for postsecondary education after graduation?

- How can transition be implemented for students who are in inclusive middle or secondary classrooms?

Until recently, the concept of transition has implied a separate postschool planning process in which students with disabilities work with special educators to develop transition plans while students without disabilities work with guidance counselors to develop graduation plans. The perception of transition as a separate planning process makes it difficult to integrate needed transition services when students are participating in the general education curriculum. For students who are capable, transition planning should not be viewed as conflicting with participation in the general education curriculum, or meeting high academic standards and graduating with a regular high school diploma.

Students who need transition services should not be forced to choose between transition services and the general education curriculum. The potential benefits of aligning transition and standards-based (general) educational systems are enormous, and include the following:

1. Transition research has demonstrated that students in successful transition and school-to-work programs are highly integrated with their nondisabled peers in both school and community activities.

2. Transition personnel now are more likely to be teachers, counselors, or coordinators who serve students with and without disabilities.

3. The IDEA and NCLB transition requirements emphasize transition practices that maximize students' integration with nondisabled peers.

A core principle for secondary students with disabilities is that the IEPs must reflect the general education curriculum and standards, participation in standardized assessments, and needed transition services. Misperceptions about the relationship of transition planning to the general education curriculum illustrate the tensions that arise between the goals of individualized educational planning and the standards-based education model (common standards for all). As one parent put it, "I don't want to have to choose between general education advantages or transition services. My son should have both" (parent of a youth with a disability, personal communication, October 10, 2005).

\section{IDEA 2004 AND BEYOND: BACKWARD PLANNING FOR TRANSITION AND SELF-DETERMINATION}

Implementing transition involves much more than what is spelled out in the language of the law. Several "facilitative" implementation processes are key to achieving effective 
transition and ensuring adequate planning for students to get them ready for the final stage of transition - the exit from high school and entry into a postsecondary setting. "Facilitative processes" means practices that state and local education agencies have developed over the years as a result of their students' experiences with transition under IDEA and their own evaluation of services. These practices are longerterm, comprehensive processes of decision making that

1. begin as the student prepares to exit middle school and make decisions and choices about the high school course of study (self-determination);

2. involve assistance with adjustment to high school;

3. involve IEP planning that defines a postsecondary goal and designs a course of study, supportive and supplemental services, and a variety of transitionrelated activities that support the postsecondary goal (Sec. 614); and

4. prepare the student and family to take an active role in planning during high school and to take responsibility for his or her own life (self-determination and self-advocacy) upon exit from high school.

Steven Covey (2004), author of the best-selling book, The Seven Habits of Highly Effective People, advised, "Begin with the end in mind." Applying Covey's statement to transition, the student and the IEP team conducts a careful backward design and planning process with a clear eye to the final outcome- the postsecondary goal. The "course of study" requirement of IDEA connects transition with curriculum standards and assessment for all students.

As mentioned earlier, IDEA 2004 shifts the age at which transition services are initiated from 14 back to age 16. For many youth this is an overwhelming challenge for which they must be prepared far in advance. Research has shown a need for early and ongoing transition planning as a means to reduce student alienation, improve attendance, and prevent school dropout (Flexer et al., 2001; Furney \& Salembrier, 2000; Martin, Huber Marshall, \& Depry, 2001; Storms, O'Leary, \& Williams, 2000).

Youth with disabilities are at greatest risk between the ages of 15 and 18. Poor outcomes for youth with disabilities underscore the need for an early support system and longer range planning, which are crucial for adolescent development and support. According to Hehir (1999), former director of the U.S. Office of Special Education Programs, high school represents a "make-or-break" time. Thus, comprehensive transition planning must begin no later than age 14 . It must begin earlier than the final year of high school (before age 16) to provide enough time to

1. prepare the student to be actively engaged in decision making and the IEP process during high school;
2. develop a course of study and related transition services that are aligned with the postsecondary goal;

3. conduct assessments needed to determine appropriate postsecondary goals, transition services, and supports;

4. prepare the student for self-determination and selfadvocacy in the postsecondary setting; and

5. prepare the youth for adult life in a variety of domains including academic, social, career-vocational, and independent living.

Recognizing the central importance of advanced planning for successful transition, many local education agencies are continuing the practice of beginning comprehensive transition planning at age 14, as was promoted under IDEA 1997. Many also are integrating transition planning into the standards-based framework for students who are in general education classes.

The early support system, which includes parents, students, general and special educators, and related service professionals, can advance transition planning of middle school students by seeking and establishing ways for them to become more involved during the IEP process. Students who take responsibility for planning their transitions and are engaged in self-determination activities early in secondary school also have been shown to take more responsibility for their lives after school (Levine, Marder, \& Wagner, 2004). Four of the most fundamental skills or knowledge that students can generalize in a variety of adult situations are

1. the ability to assess themselves, including their skills and abilities, and needs associated with their disability;

2. awareness of the accommodations they need;

3. knowledge of their legal rights to these accommodations; and

4. self-advocacy skills necessary to express their needs in educational, work, and community settings.

These skills can provide students a strong base for participating in the development of IEP goals, developing transition plans, and managing the many aspects of adult life that will become important after high school (Martin et al., 2001; Wandry \& Repetto, 1993).

\section{CONCEPTUAL FRAMEWORK: TRANSITION AS A UNIFYING FRAMEWORK}

Implementing transition programs within a standardsbased education framework presents a conceptual and practical challenge for educators, many of whom see the principles and goals as mutually exclusive. To align special 
education programs with general education reforms and improve postsecondary outcomes, IDEA 1997 and 2004 added new requirements designed to ensure that youth have greater access to the secondary education curriculum and standardized assessments.

IDEA emphasized both transition services and access to the general education curriculum. This emphasis, therefore, placed expectations on state and local education agencies to seek practical solutions for aligning secondary education and transition systems. The requirement logically holds education agencies responsible for providing appropriate transition planning through the IEP, secondary education curriculum accommodations and redesign, and interagency coordination to help students and families achieve postsecondary goals. Building upon the historical concepts of career development frameworks (Clark \& Kolstoe, 1995; Halpern, 1994; Scharff \& Hill, 1976; Ward \& Halloran, 1993; Wehman, Kregel, Barcus, \& Schalock, 1986; Will, 1986), Kohler (1998) characterized the high school years as requiring a "transition perspective" for education of youth with disabilities. Kochhar-Bryant and Bassett (2002) referred to transition as a "unifying framework" for aligning standardsbased education and transition services (see Figure 1). Transition, therefore, integrates several sets of standards.

Experts agree that, while it may be challenging, many school districts across the United States are designing education that is based on common standards as well as the right of students with disabilities to individualized education and transition planning. The transition-planning framework can be instrumental as a comprehensive, foundational framework for

- incorporating the concept of integrated transition planning and participation in a general education course of study;

- recognizing different pathways to graduation for different students;

- guiding decision making among students, families, and professionals for postsecondary planning;

- meeting universal design (UDL) criteria for flexible and widely usable curricula and environments; and

- recognizing the need for flexible combinations of academic, career-vocational classes, and communitybased work experiences to achieve different pathways to graduation.

Transition planning, therefore, is the foundational concept and integrates the four building blocks of individualized education:

1. Curriculum standards

2. Outcomes in multiple life domains

3. Opportunities to learn (accommodations and supports) (Glatthorn \& Craft-Tripp, 2000)

4. Curriculum choices (courses of study)

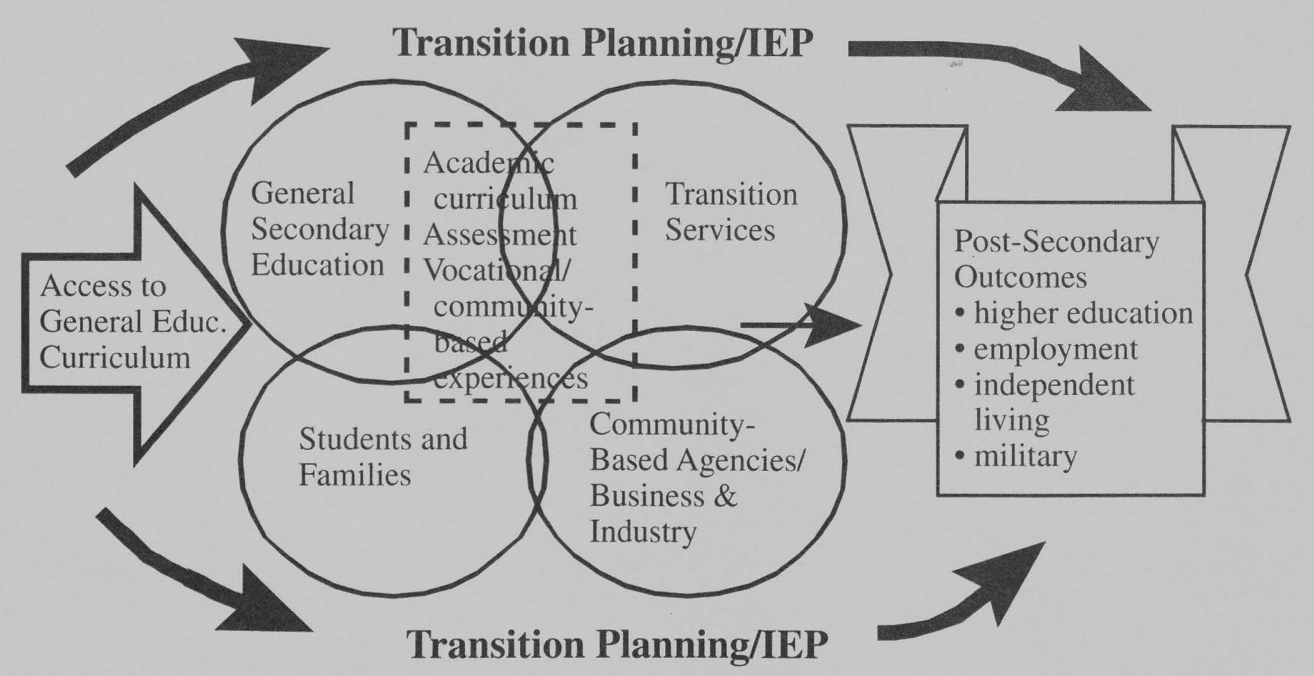

Source: From Aligning Transition and Standards-Based Education by C. A. Kochhar-Bryant \& D. S. Bassett, 2002, p. 19. Copyright (c) 2002 by The Council for Exceptional Children. Reprinted with permission. 
"Opportunity standards" are an important element in a framework for aligning standards-based education and providing individualized and appropriate transition planning. Glatthorn and Craft-Tripp (2000) synthesized the various "opportunities" that a local school has to provide for helping students achieve the performance standards now required of all students. Examples of opportunities that students with disabilities need to participate in the general education classroom follow:

- A planned program of study built around postsecondary transition goals

- An individualized education program

- Individualized instruction

- Grouping that does not stigmatize them

- A responsive curriculum

- Adequate time for learning

- Extended school-year programming

- Positive behavioral interventions

- Responsiveness to native language

- Valid assessment

Glatthorn and Craft-Tripp concluded that setting educational goals for many students with disabilities means looking beyond academic goals to a broader set of outcomes. As others have suggested (Halpern, 1994; Patton \& Dunn, 1998; Polloway, Patton, Smith, \& Roderique, 1991; Tashie, Shapiro-Barnard, Donoghue Dillon, Schuh, \& Jorgenson, 2001), focusing on a broad set of outcomes means that curricula for some students with disabilities, particularly at the secondary level, include nonacademic components and emphasis on the transition to work and preparation for adjustment to adult roles.

Transition planning to achieve postsecondary goals includes the following:

1. Academic curriculum standards

2. Occupational skill standards

3. Opportunity standards to assist the student to progress in his or her educational program (supports and accommodations)

Transition planning, the foundational concept, integrates the four building blocks of individualized education-standards, outcomes in multiple domains, opportunities, and curriculum options (see Figure 2).

In sum, transition planning blends multiple standards in a process of continuous, systematic planning and decision making to define and achieve postsecondary goals. It provides curriculum options or pathways to accommodate students' individual needs and varied postsecondary goals. The process blends academic, career-technical, and communitybased learning while addressing multiple outcome domains

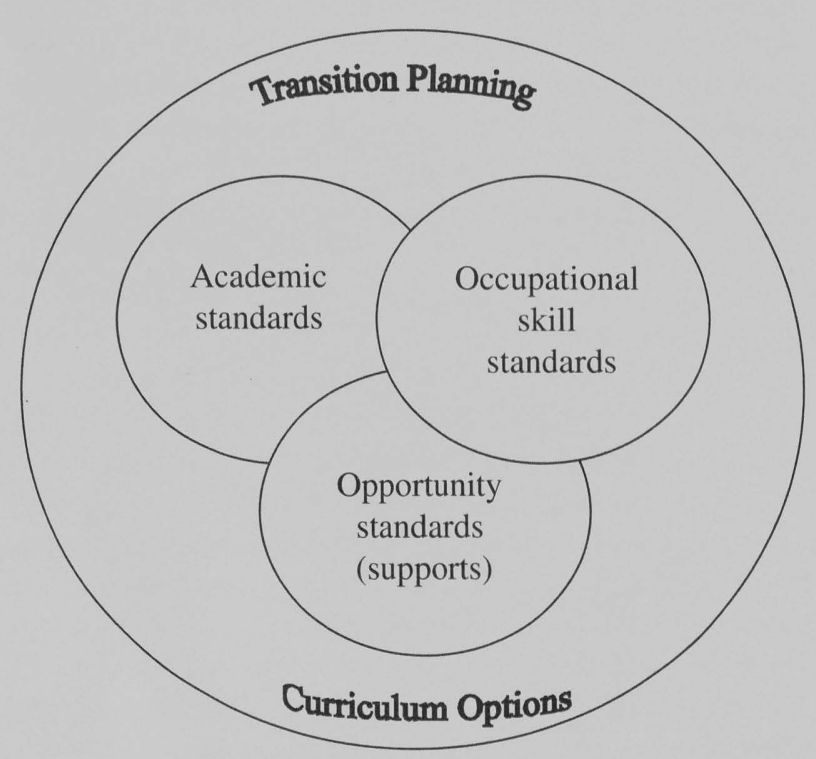

Source: Adapted from Aligning Transition and Standards-Based Education by C. A. Kochhar-Bryant \& D. S. Bassett, 2002, p. 17. Copyright (C) 2002 by The Council for Exceptional Children. Reprinted with permission.

\section{FIGURE 2 Blending Multiple Standards}

and measures and integrating appropriate aids and supports (opportunities). Transition planning, therefore, is not a single passage or "bridge" between school and adult life for students with disabilities. It is a comprehensive, coordinated planning process that provides ample time and support to prepare the youth to successfully complete a secondary program of study and to achieve postschool goals.

\section{THE IMPORTANCE OF STANDARDS-BASED REFORM}

When the Goals 2000: Educate America Act was passed in 1994, few people foresaw the seismic changes that would erupt in educational accountability for our nation's schools. Among these changes has been the mandate of standardsbased systems for all schools and teachers. These reforms, seen as Draconian by some, nonetheless have provided a structure and guidance to curriculum implementation. For students with disabilities, increased access to the general education curriculum and content standards has helped to diminish watered-down special education curricula that hinder students from fulfilling their postschool dreams and goals.

Today, an unprecedented number of students with identified disabilities are succeeding in general education courses 
and are transitioning to challenging postsecondary opportunities (Wagner, Newman, \& Cameto, 2004; Wagner, Newman, Cameto, Levine, \& Marder, 2003). Much remains to be done, however, if students with disabilities are to achieve educational parity with their typical peers. For most of these students, educational content continues to lack the "rigor, relevance, and relationships" that can bridge the gap between the educational process and the demands of adulthood (Benz et al., 2000, p. 525).

\section{High School Reform Issues}

High school reform has emerged as a serious issue in the last decade. Noguera (2004) summarized findings from several research studies and found that high schools are organizationally flawed, offer disconnected coursework with little intellectual rigor, utilize a primarily traditional lecture format, and do not expect confirmation of learning or mastery of learning except as evidenced on statewide assessments. Further, student apathy and boredom remain high, especially as peer cultures undermine academic motivation and achievement. For students with disabilities, already disenfranchised academically and socially from typical peers, these issues represent landmines that may impede progress.

Many reformers have called for the reorganization of secondary schools into smaller, more personalized learning communities (Noguera, 2004), democratization of school policies including student-centered instruction and inclusive practices (Jorgensen, 1998), and application of authentic educational curriculum and practices (Brown, 2000; Hanley-Maxwell, Phelps, Braden, \& Warren, 1999; Noguera, 2004; Phelps, 2003; Stodden, Galloway, \& Stodden, 2003; Tomlinson, 2001). The Research Institute on Secondary Education Reform (RISER) has studied high school reform efforts as related to inclusive and authentic practices for youth with disabilities, including authentic instruction, assessment, and support strategies, and concludes that these practices represent great promise in high school reform efforts.

\section{Standards-Based Reform Issues}

Thurlow (2000) reminds us that the original impetus in creating a standards-based system was to "improve teaching and learning so all students could demonstrate the knowledge and skills needed in the global economy of today and the future" (p. 10). Unfortunately, this unarguable goal often has been mired in policy and rigid application of content standards. In many places, standards-based education consists of teaching the knowledge and skills needed for statewide assessments only, with little thought or attention given to critical thinking, generalization, or educational relevance. The result has been a narrow concentration on education that does not accommodate differing learning styles or teaching approaches. Ironically, we have learned that the most effective learning is painted with a broad brush of integrated content, instructional strategies, and multiple expectations for mastery.

Tomlinson (2001) argues that academic standards should not be in conflict with what she defines as "artful teaching" and offers the following guidelines to encourage and support skillful teaching (pp. 39-46):

Guideline 1: Reflect on the purpose of education.

Guideline 2: Plan the curriculum to address all facets of learning.

Guideline 3: Plan the curriculum to help students make sense of things.

Guideline 4: Organize the curriculum so its contents are manageable for teachers and students.

Guideline 5: Design instruction so learning is invitational to students.

Guideline 6: Design instruction for focused action.

Guideline 7: Design instruction to attend to learner variance.

Guideline 8: Work in learning environments typified by safety, respect, and trust.

Guideline 9: Teach for success.

Hoover and Patton $(2004$, 2005) provide strategies for both aligning and differentiating curriculum with standardsbased content mandates that also holistically consider adaptations, student behaviors and dispositions, and instructional settings. Standards are viewed as essential components of a thoughtfully articulated, integrated approach that reflects measurable expectations and student-considered learning processes. Only in these ways-by considering educational content in concert with the dynamics of student-centered instruction - will the promise of standards-based reform be realized.

\section{Alignment of Transition-Focused Competencies With Standards-Based Content}

As we noted earlier in this article, the tenets of a standards-based educational system and of a transitionfocused educational system seem disparate at best. Can these systems be integrated in a compatible manner to provide optimal educational opportunities to students? We say-of course! The key to integration rests with the understanding that the transition process undergirds and supports all facets of secondary schooling. Transition is not just a program or a project or a set of activities that has a beginning and an end. Rather, it is a vision and a goal for unfolding the fullest potential of each individual, and it represents a systematic framework for planning to fulfill that potential (Kochhar-Bryant \& Bassett, 2002, p. 19). 
With transition as the heart of a comprehensive planning process, postsecondary goals can be set and academic standards appropriate to those goals can be taught. Content and performance standards, then, support the postsecondary goals articulated in an IEP and lend rigor and value to a student's educational plan. These standards provide structure to transition planning and at the same time assure access to general education curricula. Kochhar-Bryant and Bassett (2002) identify the components of effective transitionfocused, standards-based education as

- continuous, systematic planning, coordination, and decision making to define and achieve postsecondary goals;

- curriculum options or pathways;

- academic, career-technical, and community-based learning;

- multiple outcome domains and measures; and

- appropriate aids and supports (opportunities).

Because the transition planning process by necessity invokes a relevance to immediate and future real-life goals, the standards must provide content and expectations for mastery that have the "rigor, relevance, and relationships" mentioned earlier. We believe the most effective means by which to ensure relevance is to incorporate the principles of contextual learning into authentic learning practices.

\section{The Promise of Authentic Learning Practices}

Most of us have practiced authentic instruction in our classrooms to some extent. Secondary students may complete discrete tasks such as job applications and newspaper searches as a way of linking academic content with real-life relevance. What educators fail to do, however, is to alter the paradigm by which academic content is taught. We tend to see authentic learning practices as enhancements to teaching academic content, and not as the foundation of instruction. Just as we have emphasized that sound transition practices are the basis for effective secondary schooling, so, too, do authentic learning practices guide curriculum development and instruction. Students become engaged in learning when education is explicitly purposeful and offers relevance to life beyond the classroom (Benz et al., 2000; Bouck, 2004; Bradford, 2005; Conley, 2002; Clark, Field, Patton, Brolin, \& Sitlington, 1994; Cronin \& Patton, 1993; Ford, Davern, \& Schnorr, 2001; Glatthorn \& Craft-Tripp, 2000; HanleyMaxwell et al., 1999; Kohler \& Field, 2003; LawrenceBrown, 2004; Patton, Cronin, \& Wood, 1999; Patton \& Trainor, 2002; Stodden et al., 2003).

Hanley-Maxwell and colleagues (1999) have synthesized three essential components of successful schools that use authentic learning practices (p. 5):
1. Construction of knowledge: Students take information and construct knowledge using higher order thinking processes to transform information into knowledge.

2. Disciplined inquiry: Students draw on their knowledge base to conceptualize problems (e.g., using the scientific process with biology content).

3. Value beyond school: Students generate products that have an audience or value beyond school (e.g., letters to newspaper, published poetry, community projects) that are in contrast to products used only in schools (e.g., quizzes, tests, papers).

These three features have been found to generate highquality, in-class assessment results, as well as improvement on standards-based measures; further, they reduce achievement differences among diverse minority' and class groups (Hanley-Maxwell et al., 1999).

At its core, authentic learning uses content, materials, and activities that are framed around real-life contexts in which they would be used. What is learned is important in two ways (Hanley-Maxwell et al., 1999):

1. The relevance of student learning has an immediate or personal value to the student.

2. The learning has an eventual value beyond school.

Student motivation and engagement in learning increases as the dual value of authentic learning is emphasized (Bouck, 2004; Cole \& McLesky, 1997; Stodden et al., 2003). Further, critical thinking, problem solving, independent research skills, and cultivation of personal skills such as curiosity and perseverance are byproducts of authentic learning (Conley, 2002). For students who have significant support needs, authentic instruction offers a link to IEP goals that can be taught in the context of general education coursework (Lawrence-Brown, 2004).

Traditionally, students with disabilities have not been challenged by rigorous academic content (Johnson, Stodden, Emanual, Luecking, \& Mack, 2002). With the advent of standards-based reform and access to general education, students from all ability levels are exposed to challenging courses and higher-level content, most often taught in teacher-centered classrooms dominated by lecture format (Cole \& McLesky, 1997). Authentic learning practices offer viable means by which to mediate academically challenging content and skills by illuminating their relevance to real-life tasks.

Effective authentic learning employs a student-centered approach to content that may rely on project-based, groupfocused activities. This instructional process can be linked directly to career and/or content standards. Demonstration 
of content or skill mastery can include multiple means (e.g., traditional products, projects, oral reports, service learning) as well as generalization to other situations and environments. Generalization provides the "full circle" to content acquisition as students learn, practice, extend, and finally use the content in everyday activities and typical adult-living demands. It provides the impetus for students to become lifelong learners.

Many terms are synonymous with or related to authentic learning practices. Our favorite is contextual learning. Other terms include applied academics, functional curricula, functional academic skills, life skills, independent living skills, daily living skills, and survival skills (Patton \& Trainor, 2002). All of these terms ultimately refer to the competencies gleaned for generalization to the myriad demands of adulthood (Cronin, 1996). They also are uniquely tied to transition-focused competencies that stress mastery of skills in adult domains such as employment, education and training, social/emotional skills, community involvement, recreation and leisure, and personal responsibility. For our purposes, we will use the term contextual learning to connote the application of real-life skills into academic content.

\section{Blending Standards With Transition-Focused, Contextual Learning}

Once the principles of transition-focused contextual learning are understood, we must establish how this construct can blend with standards-based reform. These two systems, though ostensibly disparate in nature, actually can complement each other. Consider these statements (KochharBryant \& Bassett, 2002):

- Standards reflect a thinking curriculum.

- Contextual learning naturally supports higher-order thinking skills to reach standards.

- A transition focus begins with the end in mind (e.g., focus on postschool outcomes and skills).

- Blending standards and transition competencies through contextual learning will enhance academic skills and tie them to adult-focused life demands.

By using standards to support contextual learning (and not the other way around), transition-focused curriculumthat is, a curriculum tied to real-world relevance and rigorcan be established. Academic content can be taught in the general education setting, using the expertise of general and special educators. Community-based opportunities also can round out a student's educational experience and be tied directly to academic content standards.

\section{Using Career Standards and Workplace Competencies}

Presently, 28 states use academic content standards as well as career and vocational standards (Williams, 2002).
These states have a tremendous advantage in that they can clearly articulate the connection between classroom and community-based curriculum and its application to academic and vocational standards. By integrating the use of both academic and career standards, students can generalize their skills to real-world contexts.

For states without career/vocational standards, the SCANS (1991) competencies and/or state-developed work competencies (for example, see Colorado's workplace competencies: http://www.d20.co.edu/standards/workplace.html) can be used in concert with academic standards. Students who complete career and technology-based courses are more likely to earn higher wages and pursue postsecondary education (Williams, 2002). The school-to-career movement has provided the impetus for schools to envision a seamless transition between school and work that encourages both academic and vocational rigor while maintaining a future vision for students.

\section{TWO APPROACHES TO TRANSITION-FOCUSED, STANDARDS-BASED LESSON PLANNING}

If we are to respond to the need for instruction that blends transition-focused competencies with standards-based rigor, we must have a systematic way of doing so. As mentioned, many educators use elements of contextual learning, but they may not do this comprehensively or systematically. What is needed is a shift in thinking that places transition as the foundation of all instruction for secondary learners. Once this is understood and applied, a vision for relevance and rigor emerges.

When one thinks of incorporating contextual learning into academic content, there are two ways to thoughtfully plan for this. The first and most obvious is to simply infuse contextual learning into content. The infusion process can be as narrow or as broad as desired. For instance, in a health class, a teacher could infuse an entire unit on basic first-aid in which students could become certified in basic first-aid through the Red Cross training modules. Or the entire course could be modified to include contextual learning. Students might conduct research into the annual prevalence rate of classmates with the flu in their school, or study pandemics across the globe as they pertain to health, nutrition, and medical care. These skills underscore transition-focused competencies by illustrating what is needed for successful independent living. Either way, the teacher has planned the infusion process to link transition competencies and standards. Infusion of contextual learning takes time and effort and should be developed accordingly.

If a teacher does not have the time to infuse a large amount of contextual information into a class, an infusion burst may prove adequate. A burst is just that-a quick 
reference to a real-life context that connects immediate learning with the topic at hand. For example, a teacher might tie a geometry lesson into Daniel Liebeskind's gravitydefying architecture, or to the importance of correct measurement in construction. The "so what" questions add a quick link to real-life applications.

"So what kinds of jobs would need this skill?"

"So who would use this skill?"

"So how would you use these skills in everyday life?"

"So why are these skills important to learn?"

The "so what" questions reflect employment, education, independent living skills, social skills, decision making, goal setting, and a host of other competences needed for successful transition. They provide a short burst of relevance that continues to engage students and extend their learning (Patton \& Bassett, 2004).

Given the options of infusing or bursting, two approaches to instructional planning have been developed to incorporate systematic blending. In each approach, academic content is used as the foundation for the lesson. Each approach uses the same components in a different order of application. The components consist of

- academic content standards;

- ideas for contextual integration;

- description of the activity that will occur;

- linkage of the activity to the curricular reference;

- description of teacher responsibilities;

- description of student responsibilities;

- criteria for mastery of the concept or activity;

- linkages to career standards, SCANS competencies, or workplace competencies.

\section{Applying Standards to Ideas}

When standards are applied to ideas, the curricular references or materials are considered to be the anchor to instructional planning. Textbooks and professionally produced materials represent the primary means by which to organize instruction in today's schools (Ketterlin-Geller, McCoy, Twyman, \& Tindal, 2003). Because of the widespread use of textbooks, it is critical to determine their appropriateness and the optimal means by which to integrate both content standards and real-life applications, as well as the authentic assessment of skill mastery (Drake \& Burns, 2004; Nolet \& McLaughlin, 2005).

The three pillars of standards-based reform-curriculum, instruction, and assessment- provide a balanced and integrated system and complements transition-focused activities (Love, 2001). In a curriculum-based approach, we begin with the curriculum and add the standards to the process after we have designed the instruction. We apply the standards to ideas, following these steps (Patton \& Bassett, 2004):

1. Start with targeted curriculum (state, district, schoolbased materials, textbooks, etc.).

2. Identify real-world topics related to student needs (these could be identified through the IEP process as well as district scope and sequence).

3. Brainstorm activities that could be infused that reflect the real-world topics; an infusion model or a burst model may be used.

4. Explain how the activity links to the curriculum.

5. Describe what the teacher will do.

6. Describe what the students will do.

7. Describe the procedure and criteria for how the standards will be mastered.

8. List the standard(s) addressed.

9. List career standards, SCANS competencies, or workplace competencies.

An example of Applying Standards to Ideas (see Table 2) illustrates how the approach can be used. In this example, a chapter entitled, "The Thirst for Gold: How Did the Spanish Conquer Mexico and Peru?" was pulled from a middle school social studies text. The text discussed the rich clothing of the Aztecs and Incans, the diseases the Spanish conquistadores brought with them, and the mercenaries hired by the Spanish to decimate the indigenous peoples. A matrix of activities was generated reflecting transition-focused ideas (e.g., self-help and career exploration) while addressing standards.

\section{Applying Ideas to Standards}

Applying ideas to standards begins with standards and then develops appropriate curriculum around them. Because educators must be constantly aware of meeting academic content standards, instruction becomes focused on linking standards to instruction and assessment. This process lends itself nicely to creative and integrated pedagogy that can reflect life skills and contextual learning experiences, challenging academic content, and authentic assessment (Drake, 2001; Drake \& Burns, 2004; Cole \& McLesky, 1997; Glatthorn \& Craft-Tripp, 2000; Hoover \& Patton, 2005; Nolet \& McLaughlin, 2005).

In this approach, the content standard or benchmarks are targeted first, and ideas for contextual learning are generated from the standards themselves and infused into the curricular materials. The only difference between the first approach and this approach is that instead of beginning with the course materials, we begin with standards, supported by course materials. In the same way, however, transitionfocused competencies can be addressed through the infusion 


\section{TABLE 2}

Applying Standards to Ideas

Curricular Reference: Social studies material

List ideas using

\section{contextual}

activities

that relate to

the curricular

material

Best place to Collage

get stylish

clothes

How to

prevent illness

Question-
naire

New

diseases

killed people

throughout

the world

Teacher asks
students
how they
stay healthy
- questions

$\begin{array}{ll}\text { What will } & \text { What will } \\ \text { the teacher } & \text { the students } \\ \text { do? } & \text { do? }\end{array}$

Grade Level: Middle grades

Provide Group

format for

the collage

How do

people

choose

their careers?

\begin{tabular}{|c|c|c|}
\hline $\begin{array}{l}\text { Discus- } \\
\text { sion and } \\
\text { job search }\end{array}$ & $\begin{array}{l}\text { Spanish } \\
\text { soldiers } \\
\text { made a } \\
\text { decision to } \\
\text { become } \\
\text { soldiers }\end{array}$ & $\begin{array}{l}\text { Teacher } \\
\text { generates } \\
\text { questions } \\
\text { about finding } \\
\text { out about } \\
\text { jobs \& shows } \\
\text { how to do } \\
\text { an Internet } \\
\text { job search }\end{array}$ \\
\hline
\end{tabular}

Students

complete

questions \&

vaccination

record

project

$$
\text { record }
$$

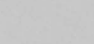

How will

you know What are the What are the

that the standards or workplace

standard benchmarks competencies

has been that will be that will be

mastered? addressed? addressed?

Share History -Problem

collage

\& relate to

clothing of

Aztecs \&

Incas

\section{Standard 3:}

Explain how

the culture of

the earliest

civilizations

spread and

interacted

solving

-Creative

thinking

-Team

member

Class dis-
cussion \&
written
summation
of precau-
tionary
measures

History

Standard 4:

Identify and

explain the

consequences

of scientific

and technolog-

ical changes

Students
perform an
Interniet job
search on a
job of their
choosing

Completion

of a form

describing

career

Economics
Standard 2:
Describe the
characteristics
that make the
U.S. economy
a mixed
economy

-Using resources

-Interpreting

-Self-management
-Demon-
strates computer literacy
—Evaluating
-Writing

Source: From Designing and Using Transition-focused Curriculum in a Standards-based World by J. R. Patton \& D. S. Bassett. Paper presented at Bresnahan-Halstead Symposium, sponsored by the University of Northern Colorado and taking place in Vail, July 2004. C) Patton and Bassett.

of applied academics. The format for this approach, then, is slightly different, as delineated by Patton and Bassett (2004):

1. Start with targeted content standards and benchmarks.

2. Identify real-world topics related to student needs (these could be identified through the IEP process, as well as district scope and sequence).

3. Brainstorm activities that could be infused reflecting the real-world topics; an infusion model or a burst model may be used.

4. Describe what the teacher will do.

5. Describe what the students will do.
6. Describe the procedure and criteria for how the standards will be mastered.

7. List career standards, SCANS competencies, or workplace competencies.

Using a high school history text that discusses the Black Death and medieval Europe, Table 3 illustrates how ideas are generated and matched to the standards. Students investigate epidemics or miracle cures and how these "cures" may be considered just as medieval as in times past; thus, students begin to think critically about the world around them.

The approaches presented here are just some of the examples of how to encourage the link between transitionfocused curriculum and standards-based education. None of 
TABLE 3

Applying Ideas to the Standard

Standard Reference: History Standard 2.3

Grade Level: High school

Benchmark: Using historical information to interpret and evaluate decisions or policies regarding contemporary issues

\begin{tabular}{|c|c|c|c|c|c|c|}
\hline $\begin{array}{l}\text { List ideas using } \\
\text { contextual } \\
\text { activities } \\
\text { to address } \\
\text { the standard }\end{array}$ & $\begin{array}{l}\text { What is the } \\
\text { activity? }\end{array}$ & $\begin{array}{l}\text { How does } \\
\text { the activity } \\
\text { link to the } \\
\text { curricular } \\
\text { reference? }\end{array}$ & $\begin{array}{l}\text { What will the } \\
\text { teacher do? }\end{array}$ & $\begin{array}{l}\text { What will the } \\
\text { students do? }\end{array}$ & $\begin{array}{l}\text { How will you } \\
\text { know that } \\
\text { the standard } \\
\text { has been } \\
\text { mastered? }\end{array}$ & $\begin{array}{l}\text { What are the } \\
\text { workplace } \\
\text { competencies } \\
\text { that will be } \\
\text { addressed? }\end{array}$ \\
\hline $\begin{array}{l}\text { Epidemics, } \\
\text { esp. the flu }\end{array}$ & $\begin{array}{l}\text { How to keep } \\
\text { healthy during } \\
\text { flu season }\end{array}$ & $\begin{array}{l}\text { People did not } \\
\text { know how to } \\
\text { avoid the plague }\end{array}$ & $\begin{array}{l}\text { I will co-lead a } \\
\text { presentation } \\
\text { with a physi- } \\
\text { cian's ass't. }\end{array}$ & $\begin{array}{l}\text { Students will } \\
\text { compose a list } \\
\text { of how to stay } \\
\text { healthy during } \\
\text { flu season }\end{array}$ & $\begin{array}{l}\text { Student- } \\
\text { generated lists } \\
\text { and class } \\
\text { discussion }\end{array}$ & $\begin{array}{l}\text { Listening, using } \\
\text { information, self- } \\
\text { management, } \\
\text { responsibility }\end{array}$ \\
\hline $\begin{array}{l}\text { Miracle cures } \\
\text { and backlashes }\end{array}$ & $\begin{array}{l}\text { Investigating } \\
\text { miracle cures } \\
\text { (example: herbs, } \\
\text { healing touch) }\end{array}$ & $\begin{array}{l}\text { During the } \\
\text { Middle Ages, } \\
\text { people used } \\
\text { witchcraft }\end{array}$ & $\begin{array}{l}\text { I will bring in } \\
\text { "miracle cures" }\end{array}$ & $\begin{array}{l}\text { Students will } \\
\text { investigate on } \\
\text { Internet truths } \\
\text { and myths } \\
\text { regarding these } \\
\text { cures }\end{array}$ & $\begin{array}{l}\text { Each group } \\
\text { will report on } \\
\text { findings on } \\
\text { each "cure" }\end{array}$ & $\begin{array}{l}\text { Interpreting, } \\
\text { using resources, } \\
\text { problem solving, } \\
\text { team member }\end{array}$ \\
\hline
\end{tabular}

Source: From Designing and Using Transition-focused Curriculum in a Standards-based World by J. R. Patton \& D. S. Bassett. Paper presented at Bresnahan-Halstead Symposium, sponsored by the University of Northern Colorado and taking place in Vail, July 2004. (C Patton and Bassett.

this can be successful, however, without the knowledge, skills, and collaboration of general and special educators.

\section{Collaboration Between General and Special Educators}

Kohler and Field (2003) emphasize the importance of linking the acquisition of school-based life skills with "ultimate inclusion" into typical community settings for adult life. Indeed, the application of contextual learning practices to blend transition competencies with content standards provides a means by which educators can envision a future for their students. True integration of transition-focused competencies with academic standards, however, requires collaboration. The collaborative process is essential to increase student achievement for all students (Duchardt, Marlow, Inman, Christensen, \& Reeves, 1999; Gable, Mostert, \& Tonelson, 2004; Walther-Thomas, Korinek, \& McLaughlin, 1999).

Coteaching practices lend themselves easily to blended instruction using standards and contextual learning. Through varied models of collaboration for instruction (e.g., one teaching/one supporting, station teaching, parallel teaching, alternate teaching, and team teaching), teachers are able to address varying learning styles, augment with hands-on and manipulative activities, and provide for community-based experiences (Fennick, 2001; Duchardt et al., 1999; Nolet \& McLaughlin, 2005; Walsh \& Jones,
2004). Koppang (2004) describes multiple uses for curriculum mapping, including developing integrated curriculum units. Hands-on, life-skills-oriented curriculum has been recognized as an effective means by which to foster collaboration between general and special educators (Mastropieri et al., 2005). In essence, collaboration and contextual learning complement and inform each other and allow for transition-focused competencies to guide academic content standards.

\section{APPLYING UNIVERSAL DESIGN PRINCIPLES TO TRANSITION}

Universal design for learning (UDL), a concept that emerged from the field of architecture, is an approach to designing products and environments for maximum usability by a diverse population. Architectural examples of UDL are ramped entrances and automatic doors (Center for Applied Special Technology, 2004; Smith \& Leconte, 2004). In educational settings, universal design means that environments and curricula are designed to be flexible and usable by students of widely varying abilities. Universal design provides a way to offer flexible curriculum and learning environments so students with widely divergent abilities all have the opportunity to access the general curriculum (and assessments) and achieve the academic content 
standards that have been established for all students in the school (Casper \& Leuchovius, 2005).

In the past, providing "access" to general education has meant enabling physical access to the classroom and, for some students, providing adaptive equipment to facilitate sensory and motor access to the curriculum. More recently, there has been a growing interest in designing curriculum, instruction, and assessment to increase access and reduce the need for individualized adaptation and accommodation (Casper \& Leuchovius, 2005). In secondary education, for students with disabilities to have meaningful access to the general curriculum, transition planning and services must be integrated. To meet the criteria of "flexible and widely usable curricula and environments," UDL applied to transition must

- recognize different pathways to graduation for students, which vary by level of support, type and emphasis of curriculum, type of assessments, and expected postschool goals;

- recognize the central role of student participation (self-determination) in the decision making;

- incorporate the concept of integrated transition planning and participation in a general education course of study; and

- recognize the need for flexible combinations of academic, career-vocational classes, and communitybased work experiences to achieve different pathways to graduation.

Universal design for learning, when paired with contextual learning and authentic assessment, provides students the means by which to demonstrate their knowledge and mastery of concepts, and to participate equally with typical peers.

\section{TRANSITION PATHWAYS AND STANDARDS-BASED EDUCATION}

For some students with disabilities, the typical planning process for application for work or to a 2- or 4-year college proceeds much the same way as it does for students without disabilities. For many students with disabilities, however, decisions about postsecondary choices often are complex and require long-term advanced planning tailored to their individual needs and postschool goals. A pathways approach provides a framework for examining students' needs and goals early in their educational program, long before graduation is upon them, and developing a course of preparation to achieve those goals.

Transition services can be clustered into pathways or service patterns arranged to meet the needs of students with different long-term goals. These pathways vary by level of support, type and emphasis of curriculum, type of assessments, and expected postschool placement and service needs. A pathways approach also provides a framework for examining student needs and goals early in their educational program, long before graduation is upon them, and developing a course of preparation to achieve those goals. Although some students need time-limited transition supports and others need ongoing services, the transition planning process for students with disabilities should begin early as they enter secondary education.

For students without disabilities, such long-range vision and secondary planning to achieve postsecondary goals is the typical model that begins as the student exits from middle school and makes choices for a high school course of study. Table 4 presents an example of pathways and levels of support for students with different postsecondary goals.

TABLE 4

Pathways and Levels of Support in Transition

\begin{tabular}{|c|c|c|c|c|}
\hline 1. Academic & Academic & Academic/standardized & High & College enrollment \\
\hline $\begin{array}{l}\text { 2. Career-Technical } \\
\text { Training }\end{array}$ & $\begin{array}{l}\text { Vocational } \\
\& \text { Social }\end{array}$ & $\begin{array}{l}\text { Vocational \& community-based } \\
\text { "authentic" assessments }\end{array}$ & High & $\begin{array}{l}\text { Vocational-technical } \\
\text { school or apprenticeship }\end{array}$ \\
\hline $\begin{array}{l}\text { 4. Supported } \\
\text { Setting }\end{array}$ & $\begin{array}{l}\text { Social \& } \\
\text { Independent Living }\end{array}$ & $\begin{array}{l}\text { Social, adaptive behavior, and } \\
\text { independent living skills } \\
\text { assessments }\end{array}$ & $\begin{array}{l}\text { Moderate to } \\
\text { limited }\end{array}$ & $\begin{array}{l}\text { Supported employment } \\
\text { and supervised living }\end{array}$ \\
\hline
\end{tabular}




\section{CONCLUSION}

In the first decade of this new millennium, the journey toward achieving improved transition outcomes for our nation's youth is just beginning. This is an era of much experimentation in aligning education, employment preparation, and transition supports that will profoundly affect the lives of youth with disabilities well into this new century. A heightened national effort is under way to identify promising and best practices in education that promote successful transition.

The concept of transition as a comprehensive unified planning framework for youth undergirds these promising practices. National investment in transition demonstrates to the nation and the world a national commitment to the welfare, self-determination, and full participation of all youth in their communities.

\section{REFERENCES}

Americans with Disabilities Act of 1990, Pub. L. 101-336, 42 U.S.C. 12101 (1991).

Benz, M., Lindstrom, L., \& Yovonoff, P. (2000). Improving graduation and employment outcomes of students with disabilities: Predictive factors and student perspectives. Exceptional Children, 6(4), 509-529.

Barr, R. D., \& Parrett, W. H. (2001). Hope fulfilled for at-risk and violent youth: K-12 programs that work. Needham Heights, MA: Allyn \& Bacon.

Blalock, G., \& Benz, M. (1999). Using community transition teams to improve transition services (Pro-Ed Series on Transition). Austin, TX: Pro-Ed.

Bradford, M. (2005). Motivating students through project-based service learning. THE Journal, 32, 29-31.

Bouck, E. C. (2004). State of curriculum for secondary students with mild mental retardation. Education and Training in Developmental Disabilities, 39, 169-176.

Brown, D. E. (2000). Connected learning. Leadership, 30, 32-33.

Casper, B., \& Leuchovius, D. (2005). Universal design for learning and the transition to a more challenging academic curriculum: Making it in middle school and beyond. National Center for Secondary Education and Transition.

Center for Applied Special Technology. (2004). Universal design for learning. Wakefield, MA: CAST. Retrieved December 29, 2005, from http://www.cast.org/about/index.cfm?i=231

Clark, G. M., Field, S., Patton, J. R., Brolin, D. E., \& Sitlington, P. L. (1994). Life skills instruction: A necessary component for all students with disabilities. A position statement of the Division on Career Development and Transition. Career Development for Exceptional Individuals, 17, 125-134.

Clark, G., \& Kolstoe, O. (1995). Career development and transition education for adolescents with disabilities (3rd ed.). Boston: Allyn \& Bacon.

Clark, G. M., Sitlington, P., \& Kolstoe, O. P. (2000). Transition education and services for adolescents with disabilities (3rd ed.). Boston: Allyn \& Bacon.
Cole, C. M., \& McLesky, J. (1997). Secondary inclusion programs for students with mild disabilities. Focus on Exceptional Children, 29 , $1-15$.

Colorado Department of Education. (n.d.). Colorado workplace competencies. Retrieved February 10, 2006, from http://www.d20 .co.edu/standards/workplace.html

Conley, D. T. (2002). Preparing students for life after high school. Educational Leadership, 59, 60-63.

Covey, S. (2004). The seven habits of highly effective people. New York: Free Press.

Cronin, M. E. (1996). Life skills curricula for students with learning disabilities: A review of the literature. Journal of Learning Disabilities, 29, 52-58.

Cronin, M. E., \& Patton, J. R. (1993). Life skills instruction for all students with special needs: A practical guide for integrating real-life content into the curriculum. Austin, TX: Pro-Ed.

deFur, S. (2000). Designing individualized education program (IEP) transition plans (ERIC Digest E598). Arlington, VA: ERIC Clearinghouse on Disabilities and Gifted Education.

Drake, S. M. (2001). Castles, kings ... and standards. Educational Leadership, 59, 38-42.

Drake, S. M., \& Burns, R. C. (2004). Meeting standards through integrated curriculum. Alexandria, VA: Association for Supervision and Curriculum Development.

Duchardt, B., Marlow, L., Inman, D., Christensen, P., \& Reeves, M. (1999). Collaboration and co-teaching: General and special education faculty. Clearinghouse, 72, 186-190.

Education Policy Reform Research Institute. (2004). Ensuring accountability for all children in an era of standards-based reform: Alternate achievement standards. Arlington, VA: Author.

Eisenman, L. T., \& Chamberlin, M. (2001). Implementing selfdetermination activities: Lessons from schools. Remedial and Special Education, 22, 138-147.

Fennick, E. (2001). Coteaching: An inclusive curriculum for transition. Teaching Exceptional Children, 35, 60-66.

Flexer, R., Simmons, T., Luft, P., \& Baer, R. (2001). Transition planning for secondary students with disabilities. Columbus, $\mathrm{OH}$ : Merrill Education.

Ford, A., Davern, L., \& Schnorr, R. (2001). Learners with significant disabilities. Remedial and Special Education, 22, 214-222.

Furney, K., \& Salembrier, G. (2000). Rhetoric and reality: A review of the literature on parent and student participation in the IEP and transition planning process. In D. R. Johnson \& E. J. Emmanuel (Eds.), Issues influencing the future of transition programs and services in the United States (pp. 111-126). Minneapolis: University of Minnesota, Institute on Community Integration.

Gable, R. A., Mostert, M. P., \& Tonelson, S. W. (2004). Assessing professional collaboration in schools: Knowing what works. Preventing School Failure, 48, 4-8.

German, S., Martin, J., Marshall, L., \& Sale, H. (2000). Promoting self-determination: Using "Take Action" to teach goal attainment. Career Development for Exceptional Individuals, (Spring) 23(1), 27-38.

Glatthorn, A., \& Craft-Tripp, M. (2000). Standards-based learning for students with disabilities. Larchmont, NY: Eye on Education, Inc.

Gordon, H. (1999). History and growth of vocational education in America. Needham Heights, MA: Allyn \& Bacon.

Halpern, A. S. (1994). The transition of youth with disabilities to adult life: A position statement of the Division on Career Development 
and Transition. Career Development for Exceptional Individuals, $17(2), 115-124$

Hanley-Maxwell, C., Phelps, L. S., Braden, J., \& Warren, V. (1999, July). Schools of authentic and inclusive learning (Research Institute on Secondary Education Reform [RISER] Issue Brief No. 1). Madison: University of Wisconsin-Madison. Retrieved January 15, 2006, from http://www.wcer.wisc.edu/riser/Brief\%201.pdf

Hehir, T. (1999). Begin early, end well. The School Administrator, October, 1999. Retrieved December 27, 2005, from http://www .aasa.org/ publications/archive

Hoover, J. J., \& Patton, J. R. (2004). Differentiating standards-based education for students with diverse needs. Remedial and Special Education, 25, 74-78.

Hoover, J. J., \& Patton, J. R. (2005). Curriculum adaptations for students with learning and behavior problems (3rd ed.). Austin, TX: Pro-Ed.

Individuals with Disabilities Education Act of 1990, Pub. L. 101-476, 20 U.S.C. 1400 (1997).

Individuals with Disabilities Education Act Amendments of 1997, Pub. L. 105-17, 20 U.S.C. Chapter 33 (1997).

Individuals with Disabilities Education Act of 2004. 20 U. S. C. $\$ 1400$ et seq. (2004).

Izzo, M., Hertzfeld, J., Simmons-Reed, E., \& Aaron, J. (2001). Promising practices: Improving the quality of higher education for students with disabilities. Disability Studies Quarterly, 21(1).

Jennings, J. (1995). A brief history of the federal role in education: Why it began and why it is still needed. Washington, DC: Center on Education Policy.

Jennings, J. (2000). The future of the federal role in elementary and secondary education. Washington, DC: Center on Education Policy.

Jennings, J. (2003). From the capitol to the classroom: State and federal efforts to implement the No Child Left Behind Act. Washington, DC: Center on Education Policy.

Johnson, D. R., Stodden, R. A., Emanual, E. J., Luecking, R., \& Mack, M. (2002). Current challenges facing secondary education and transition services: What research tells us. Exceptional Children, 68, 519-531.

Jorgensen, C. M. (Ed.). (1998). Restructuring high schools for all students: Taking inclusion to the next level. Baltimore: Paul $\mathrm{H}$. Brookes.

Ketterlin-Geller, L. R., McCoy, J. D., Twyman, T., \& Tindal, G. (2003). How do critical thinking measures fit within standards-based reform? Assessment for Effective Instruction, 28, 37-48.

Kochhar-Bryant, C., \& Bassett, D. (2002). Aligning transition and standards-based education. Columbus, $\mathrm{OH}$ : Merrill/Prentice Hall.

Kohler, P. (1998). Implementing a transition perspective of education. In F. Rusch \& J. Chadsey (Eds.), Beyond high school: Transition from school to work (pp. 179-205). Belmont, CA: Wadsworth Publishing.

Kohler, P. D., \& Field, S. (2003). Transition-focused education: Foundation for the future. Journal of Special Education, 37, 174-183.

Koppang, A. (2004). Curriculum mapping: Building collaboration and communication. Intervention in School and Clinic, 39, 154-161.

Lawrence-Brown, D. (2004). Differentiated instruction: Inclusive strategies for standards-based learning that benefit the whole class. American Secondary Education, 32, 34-62.

Levine, P., Marder, C., \& Wagner, M. (2004). Services and supports for secondary school students with disabilities. A special topic report of findings from the National Longitudinal Transition Study-2 (NLTS2). Menlo Park, CA: SRI International.
Love, N. (2001). The heart of systemic reform. ENC Focus, 8, 14-15.

Martin, J. E., Huber Marshall, L., \& Depry, R. L. (2001). Participatory decision-making. In R. Flexer, T. Simmons, P. Luft, \& R. Baer (Eds.), Transition planning for secondary students with disabilities. Columbus, OH: Merrill Prentice-Hall.

Mastropieri, M. A., Scruggs, T. E., Graetz, J., Norland, J., Gardizi, W., \& McDuffie, K. (2005). Case studies in co-teaching in the content areas: Successes, failures, and challenges. Intervention in School and Clinic, 40, 260-270.

McDonnell, L. M., McLaughlin, M. J., \& Morison, P. (1997). Educating one \& all: Students with disabilities and standards-based reform. Washington, DC: National Academy Press.

National Center for Education Statistics. (2004). The Condition of Education in Brief 2004 (NCES 2004076). Washington, DC: U.S. Department of Education.

National Council on Disability. (2000). Transition and Postschool Outcomes for Youth with Disabilities: Closing the Gaps to Postsecondary Education and Employment. Washington, DC: Author.

No Child Left Behind Act of 2001, Pub.L. 107-110, 20 U.S.C. $\$ 301$ et seq.

Noguera, P. A. (2004). Special topic/Transforming high schools. Educational Leadership, 61, 26-31.

Nolet, V., \& McLaughlin, M. J. (2005). Accessing the general curriculum: Including students with disabilities in standards-based reform (2nd ed.). Thousand Oaks, CA: Corwin Press.

Patton, J. R., \& Bassett, D. S. (2004, July). Designing and using transition-focused curriculum in a standards-based world. Paper presented at Bresnahan-Halstead Symposium in Vail, sponsored by University of Northern Colorado.

Patton, J. R., Cronin, M. E., \& Wood, S. (1999). Infusing real-life topics into existing curricula at the elementary, middle, and high school levels: Recommended procedures and instructional examples. Austin, TX: Pro-Ed.

Patton, J. R., \& Dunn, C. (1998). Transition from school to young adulthood: Basic concepts and recommended practices. Austin: Pro-Ed.

Patton, J. R., \& Trainor, A. (2002). Using applied academics to enhance curricular reform in secondary education. In C. A. KochharBryant and D. S. Bassett (Eds.), Aligning transition and standardsbased education (pp. 55-76). Arlington, VA: Council for Exceptional Children.

Phelps, L. A. (2003). High schools with authentic and inclusive learning practices: Selected features and findings. National Center on Secondary Education and Transition Research to Practice Brief, 2(2). Retrieved March 14, 2006, from http://www.ncset.org/publi cations/viewdesc.asp?id=1096

Polloway, E. A., Patton, J. R., Smith, J. D., \& Roderique, T. W. (1991). Issues in program design for elementary students with mild retardation: Emphasis on curriculum development. Education and Training in Mental Retardation, 26, 142-150.

President's Commission on Excellence in Special Education. (2002). A New Era: Revitalizing Special Education for Children and their Families. Jessup, MD: Educational Publications.

Scharff, D., \& Hill, J. (1976). Between two worlds: Aspects of transition from school to work. London: Consultant Books.

Secretary's Commission on Achieving Necessary Skills, U.S. Department of Labor (1991). What work requires of schools: A SCANS report for American 2000. Washington, DC: U.S. Government Printing Office. 
Section 504 of the Rehabilitation Act of 1973, as amended 29 U.S.C. $\S$ 79.

Smith, F., \& Leconte, P. (2004). Universal design for learning: Assuring access and success for all. VSTE Journal, 19(1), 25-29. Retrieved December 27, 2004, from http://www.vste.org/commu nication/journal

Stodden, R. A., Galloway, L. M., \& Stodden, N. J. (2003). Secondary school curricula issues: Impact on postsecondary students with disabilities. Exceptional Children, 70, 9-25.

Storms, J., O'Leary, E., \& Williams, J. (2000). The Individuals with Disabilities Education Act of 1997 transition requirements: A guide for states, districts, schools, universities and families. Minneapolis: University of Minnesota, National Transition Network Institute on Community Integration (UAP).

Tashie, C., Shapiro-Barnard, S., Donoghue Dillon, A., Schuh, M., \& Jorgenson, C. (2001). Changes in latitudes, changes in attitudes: The role of the inclusion facilitator. Nottingham, UK: Inclusive Solutions.

Thompson, J. R., Fulk, B. M., \& Piercy, S. W. (2000). Do individualized transition plans match the postschool projections of students and parents? Career Development for Exceptional Individuals, 23, 3-26.

Thurlow, M. (2000). Standards-based reform and students with disabilities: Reflections on a decade of change. Focus on Exceptional Children, 33, 1-16.

Tomlinson, C. (2001). Standards and the art of teaching: Crafting highquality classrooms. NASSP Bulletin, 85, 38-47.

Wagner, M., Newman, L., \& Cameto, R. (2004, April). Changes over time in the secondary school experiences of students with disabilities. A report of findings from the National Longitudinal Transition Study-2 (NLTS2). Executive Summary. Menlo Park, CA: SRI International. Retrieved March 14, 2006, from http://nlts2.org/ reports/changestime_execsum.html

Wagner, M., Newman, L., Cameto, R., Levine, R., \& Marder, C. (2003, December). Going to school: Instructional contexts, programs, and participation of secondary school students with disabilities. A report from the National Longitudinal Transition Study-2 (NLTS2). Executive Summary. Menlo Park, CA: SRI International. Retrieved March 14, 2006, from http://nlts2.org/pdfs/goschool_ execsum.pdf

Walsh, J. M., \& Jones, B. (2004). New models of cooperative teaching. Teaching Exceptional Students, 36, 14-20.

Walther-Thomas, C., Korinek, L., \& McLaughlin, V. L. (1999). Collaboration to support students' success. Focus on Exceptional Children, 32, 1-18.

Wandry, D., \& Repetto, J. (1993, March). Transition services in the IEP. NICHCY Transition Summary, 3(1), 1-28.

Ward, M., \& Halloran, W. (1993). OSERS News in Print: Transitions, 6(1). U.S. Department of Education, Office of Special Education Programs.
Wehman, P. H., Kregel, J., Barcus, J. M., \& Schalock, R. L. (1986) Vocational transition for students with developmental disabilities. In W. E. Kiernan \& L. Stark (Eds.), Pathways to employment for adults with developmental disabilities (pp. 113-127). Baltimore: Paul H. Brookes.

Will, M. (1986). Educating children with learning problems: A shared responsibility. A report to the Secretary. Washington, DC: U.S. Department of Education.

Williams, J. M. (2002). Using school-to-career strategies, workplace competencies, and industry skill standards to enhance the transition process in standards-based education. In C. A: KochharBryant and D. S. Bassett (Eds.), Aligning transition and standardsbased education (pp. 77-90). Arlington, VA: Council for Exceptional Children.

Ysseldyke, J. (1997). Assessment terminology, SCASS on Assessment of Special Education Students. Minneapolis: National Center on Educational Outcomes.

Ysseldyke, J., Thurlow, M., Kozleski, E., \& Reschly, D. (1998). Accountability for the results of educating students with disabilities: Assessment conference report on the new Assessment provisions of the 1997 Amendments to the Individuals with Disabilities Education Act. Minneapolis: National Center on Educational Outcomes.

\section{STATEMENT OF OWNERSHIP, MANAGEMENT AND CIRCULATION}

Date of Filing: September, 30, 2006

Title of Publication: Focus on Exceptional Children

Frequency of Issue: Monthly (except June, July \& August)

Location of Known Office of Publication: 9101 E. Kenyon Ave., Suite 2200, Denver, $\mathrm{CO} 80237$

Location of Headquarters of Publisher: 9101 E. Kenyon Ave., Suite 2200, Denver, CO 80237

Name and Address of Publisher, Editor, and Managing Editor: Stanley F. Love, 9101 E. Kenyon Ave., Suite 2200, Denver, CO 80237

Owner: Love Publishing Company

Extent and Nature of Circulation:

Total No. Copies Printed

Paid Circulation

Sales through Dealers, etc.

Mail Subscriptions

Other Classes Mailed Through USPS

Total Paid Circulation

Free Distribution Outside the Mail

Free Distribution

Total Distribution

Office Use and Left Over

Total

$\begin{array}{cc}\begin{array}{c}\text { Average No. Copies } \\ \text { Each Issue During } \\ \text { Preceding 12 Months }\end{array} & \begin{array}{c}\text { Single Issue } \\ \text { Nearest } \\ \text { Filing Date } \\ 1612\end{array} \\ 1600 \\ 180 & 210 \\ 1112 & 1113 \\ 100 & 115 \\ 1392 & 1438 \\ 41 & 38 \\ 95 & 75 \\ 1528 & 1551 \\ 84 & 49 \\ 1612 & 1600\end{array}$

I certify that the statements made by me above are correct and complete.

(Signed) Stanley F. Love, Publisher 


\section{Professional update}

\section{Learning Disabilities Association of America}

February 14-17, 2007

Westin Hotel \& Lawrence Convention Center

Pittsburgh, Pennsylvania

Contact: info@LDAmerica.org

412-341-1515

\section{Midwest Symposium for Leadership in} Behavior Disorders

February 22-23, 2007

Hyatt Regency Crown Center

Kansas City, Missouri

Contact: www.mslbd.org

913-599-3311
National Association of School Psychologists Annual Convention

March 27-31, 2007

Hilton New York Hotel and Sheraton New York Hotel

New York, New York

Contact: NASP

4340 East West Highway, Suite 402

Bethesda, MD 20814

301-657-0270

Fax: 301-657-0275

\section{Council for Exceptional Children}

April 18-21, 2007

Kentucky International Convention Center

Louisville, Kentucky

Contact: www.cec.sped.org

703-620-3660 